\title{
DESIGNING OF THERMAL TREATMENT PARAMETERS FOR TOMATO SAUCES
}

\author{
Asnate Kirse-Ozolina ${ }^{1}$, Evalds Raits ${ }^{2}$, Inga Ciprovica ${ }^{1}$ \\ ${ }^{1}$ Latvia University of Life Sciences and Technologies, Latvia; ${ }^{2}$ Kronis Ltd., Latvia \\ asnate.kirse@1lu.lv, evalds.raits@gmail.com, inga.ciprovica@1lu.lv
}

\begin{abstract}
In contrast to the commercial treatment parameters currently used for the production of tomato sauces in the processing plant, this study offers new temperature and time combinations for heating, holding and cooling of products. The aim of the current study was to model the effect of time-temperature conditions for the pasteurisation/sterilisation process on the quality of different tomato sauces. Four pasteurisation and sterilization tests $\left(20-3-21 / 95,20-10-20 / 95,20-5-20 / 110\right.$ and $\left.20-5-24 / 110\left(\mathrm{~min} \cdot{ }^{\circ} \mathrm{C}^{-1}\right)\right)$ were carried out at 95 and $110{ }^{\circ} \mathrm{C}$ to obtain the kinetic constants of the simulated process. By measuring the product temperature in the time interval $1 \mathrm{~min}$ through inserting the loggers into the glass jars during thermal treatment, the achieved F-value was analysed. The temperature of the product was measured starting from the heating process till the end of cooling. $\mathrm{F}_{85}=5$ min with $\mathrm{z}=8.9$ were used for the study as reference value. $\mathrm{pH}$, water activity, total plate count and colony forming units of sulfite-reducing clostridia were determined according to standard methods. Experimentally chosen thermal treatment parameters showed that the reference F-value can be achieved by using 20-10-20/95 $\left(\mathrm{min} \cdot{ }^{\circ} \mathrm{C}^{-1}\right)$ and 20-5-20/110 or 20-5-24/110 $\left(\mathrm{min} \cdot{ }^{\circ} \mathrm{C}^{-1}\right)$ time-temperature combinations. The newly established time-temperature combinations could be used for tomato sauces production and achieve products safety and shelf-life criteria.
\end{abstract}

Keywords: F-value, tomato sauces, water activity, $\mathrm{pH}$, total plate count.

\section{Introduction}

Tomato sauces are widely consumed products, and consumer's acceptance of tomato sauces is highly correlated to their quality characteristics, such as colour, flavour and texture. Sensory attributes and nutritional value of tomato sauces are dependent on the products ingredients and thermal treatment parameters.

Effects of thermal treatment on the quality of tomato sauces have been widely studied, but till nowadays producers of commercial products search the appropriate time-temperature conditions for tomato products quality assurance with the aim to reduce the production costs on energy resources. The designing of thermal treatment parameters for tomato sauces production is one of the most important engineering tools to provide safety and nutrition value of often consumed goods. The recommended pasteurisation temperature of tomato products with $\mathrm{pH} 3.7-4.2$ ranges from 85 till $100{ }^{\circ} \mathrm{C}$ within the temperature in the core of the product around of $75-80{ }^{\circ} \mathrm{C}[1 ; 2]$. Sometimes different kinetic factors (F-value, z-value) are applied depending on whether the process core temperature is above or below the reference temperature. Product $\mathrm{pH}$ is also effective to allow the softening of the thermal treatment pattern. The required F-values for thermal treatment of ketchup and tomato products are summarised in Table 1.

Table 1

Pasteurisation value (F-value) for commercial tomato products

\begin{tabular}{|c|c|c|}
\hline Product & Approximate F value & Sources \\
\hline Ketchup (1\% acidity) & $F_{71}=15 \mathrm{~min}$ or hot fill at $82^{\circ} \mathrm{C}$ & Taylor, Crosby, 2006 [3] \\
\hline Tomato products stored at & $F_{93}>20 \mathrm{~min}$, if $\mathrm{pH}=3.9-4.6$ & Holdsworth, Simpson, \\
ambient temperature & $F_{93.3}^{8.9}=5 \mathrm{~min}$, if $\mathrm{pH}=4.0-4.3$ & 2007 [4] \\
& $F_{93.3}^{8.9}=3 \mathrm{~min}$, if $\mathrm{pH}=4.2$ & Tucker, 1999 [5] \\
\hline Tomato based products & $F_{85}=5 \mathrm{~min}$, if $\mathrm{pH} \mathrm{3.7-4.2}$ & Tucker, Featherstone, \\
(ketchup) & $F_{93.3}^{8.9}=2.5 \mathrm{~min}$, if $4.1<\mathrm{pH}<4.2$ & 2011 [6] \\
& $F_{93.3}^{8.9}=1-5 \mathrm{~min}$, if $\mathrm{pH}=4.2-4.5$ & \\
\hline
\end{tabular}

The microflora of tomato products is changeable. In pasteurised acid products $(\mathrm{pH}<4.5)$, Alicyclobacillus acidoterrestris produces spoilage of aroma and taste in shelf stable products, if these products are stored at relatively high temperature [7]. Sufficient destruction of Alicyclobacillus acidoterrestris in acid products requires the pasteurisation temperature of $95^{\circ} \mathrm{C}$. Within $\mathrm{pH}$ range 3.8 to 4.5 , heat resistant Bacillus coagulans var. thermoacidurans may grow, in addition at product 
$\mathrm{pH}>3.8$ butyric anaerobes may grow, too [7]. The reduction of microorganisms' growth by different techniques or product's ingredients/additives helps provide the stable product. Therefore, the selection of appropriate time-temperature conditions provides safety of tomato sauces, as well as allows to promote higher nutritional value of products.

The aim of the current study was to model the effect of time-temperature conditions for the pasteurisation/sterilisation process on the quality of different tomato sauces.

\section{Materials and methods}

The characteristic of the study object

Tomato sauce samples were produced from tomato puree with addition of seasonings on a commercial scale. The main ingredients and quality parameters of the commercial samples used in the study are summarized in Table 2 .

Table 2

Main ingredients and quality parameters of commercial tomato sauces set by producer

\begin{tabular}{|c|c|c|c|c|c|}
\hline Product & $\begin{array}{c}\text { Product } \\
\text { code }\end{array}$ & Ingredients & $\mathbf{p H}$ & $\begin{array}{c}\text { Salt } \\
\text { content, \% }\end{array}$ & $\begin{array}{c}\text { Total } \\
\text { solids, \% }\end{array}$ \\
\hline $\begin{array}{c}\text { Classical } \\
\text { tomato sauce }\end{array}$ & $\mathrm{TS}_{\mathrm{c}}$ & $\begin{array}{c}\text { Tomato puree, rapeseed oil, } \\
\text { sugar, marinated garlic, salt, } \\
\text { spices }\end{array}$ & $4.0-4.3$ & 2.2 & $9.0-13.0$ \\
\hline $\begin{array}{c}\text { Tomato sauce } \\
\text { with } \\
\text { seasonings }\end{array}$ & $\mathrm{TS}_{\mathrm{s}}$ & $\begin{array}{c}\text { Water, tomato puree, sugar, } \\
\text { celery roots, thickener } \\
\text { (modified corn starch), salt, } \\
\text { dried tomatoes, seasonings, } \\
\text { celery, parsley }\end{array}$ & $3.8-4.5$ & 2.3 & $18.0-29.0$ \\
\hline $\begin{array}{c}\text { Tomato sauce } \\
\text { without food } \\
\text { additives }\end{array}$ & $\mathrm{TS}_{\mathrm{E}}$ & $\begin{array}{c}\text { Water, tomato puree, sugar, } \\
\text { salt, wine vinegar, corn } \\
\text { starch, citrus fibres, spices }\end{array}$ & $3.8-4.5$ & 2.1 & $24.0-29.0$ \\
\hline
\end{tabular}

The thermal parameters for the commercial tomato products (control samples) used on the commercial scale are $40 \mathrm{~min}$ for heating, $20 \mathrm{~min}$ for holding at $110^{\circ} \mathrm{C}$ and $30 \mathrm{~min}$ for cooling (40-2030/110). The quality indices of the control samples are summarized in Table 3.

Table 3

Quality indices of control samples used in the study

\begin{tabular}{|c|c|c|c|c|}
\hline Sample & $\mathbf{p H}$ & $\boldsymbol{a}_{w}$ & $\begin{array}{c}\text { Total plate count } \\
\text { (TPC), CFU· } \mathbf{g}^{-\mathbf{1}^{*}}\end{array}$ & $\begin{array}{c}\text { Sulfite-reducing } \\
\text { clostridia, CFU. } \mathbf{g}^{-1}\end{array}$ \\
\hline $\mathrm{TS}_{\mathrm{c}}$ & $4.13 \pm 0.00$ & $0.978 \pm 0.000$ & $<100$ & $<10^{* * *}$ \\
\hline $\mathrm{TS}_{\mathrm{S}}$ & $4.19 \pm 0.00$ & $0.964 \pm 0.000$ & $<100$ & $<10^{* * *}$ \\
\hline $\mathrm{TS}_{\mathrm{E}}$ & $4.15 \pm 0.00$ & $0.962 \pm 0.000$ & $<100$ & $<10^{* * *}$ \\
\hline
\end{tabular}

* - maximal value $\left(1 * 10^{4} \mathrm{CFU} \cdot \mathrm{g}^{-1}\right)$ set by the Regulation of the Cabinet Ministers $\mathrm{N}^{\circ} 461 / 2014$ "Requirements for food quality schemes, procedures for the implementation, operation, monitoring, and control thereof" ** - below the detection limit set by ISO 15213:2003

\section{The designing of thermal treatment and storage conditions}

The pasteurisation and sterilisation tests were carried out to obtain safe food product with the producer's set quality and sensory indices. Four pasteurisation and sterilization tests were carried out at 95 and $110{ }^{\circ} \mathrm{C}$ to obtain the kinetic constants of the simulated process. The tested thermal treatment parameters are shown in Table 4.

Immediately after thermal treatment, the processed products were cooled down rapidly till the core product temperature was $66^{\circ} \mathrm{C}$ or below.

The experimental samples were kept at $30^{\circ} \mathrm{C}$ for 2 months. The chosen temperature corresponds to accelerated shelf life studies. This process is performed using the $\mathrm{Q}_{10}$ value. The $\mathrm{Q}_{10}$ value of a product is the temperature quotient for a $10^{\circ} \mathrm{C}$ temperature difference $[8 ; 9]$, as expressed in the equation below: 
Accelerated shelf life $=T\left({ }^{\circ} \mathrm{C}\right)+10^{\circ} \mathrm{C}$,

where $T$-ambient temperature for tomato sauces storage $\left(20 \pm 2{ }^{\circ} \mathrm{C}\right),{ }^{\circ} \mathrm{C}$.

If the product shows stability during the storage time, then the expected shelf life multiples with 2 .

Table 4

Chosen thermal treatment parameters for experimental tomato sauces

\begin{tabular}{|c|c|c|c|c|c|c|c|}
\hline $\begin{array}{l}\text { Product } \\
\text { code }\end{array}$ & $\begin{array}{c}\text { Product } \\
\text { temperature } \\
\text { prior } \\
\text { treatment, }{ }^{\circ} \mathrm{C}\end{array}$ & $\begin{array}{c}\text { Thermal } \\
\text { treatment } \\
\text { temperature, } \\
{ }^{\circ} \mathrm{C}\end{array}$ & $\begin{array}{l}\text { Temperature } \\
\text { in the core of } \\
\text { the product at } \\
\text { cold point, }{ }^{\circ} \mathrm{C}\end{array}$ & $\begin{array}{l}\text { Heating } \\
\text { time, } \\
\text { min }\end{array}$ & $\begin{array}{l}\text { Holding } \\
\text { time, } \\
\text { min }\end{array}$ & $\begin{array}{l}\text { Cooling } \\
\text { time, } \\
\text { min }\end{array}$ & $\begin{array}{c}\text { Abbreviation } \\
\text { for time- } \\
\text { temperature } \\
\text { combinations } \\
\text { used in the study }\end{array}$ \\
\hline \multirow{4}{*}{$\mathrm{TS}_{\mathrm{c}}$} & 77 & 95 & 80 & 20 & 3 & 21 & $20-3-21 / 95$ \\
\hline & 77 & 95 & 85 & 20 & 5 & 20 & $20-10-20 / 95$ \\
\hline & 63 & 110 & 80 & 15 & 1 & 22 & $15-1-22 / 110$ \\
\hline & 57 & 110 & 85 & 20 & 5 & 20 & $20-5-20 / 110$ \\
\hline \multirow{4}{*}{$\mathrm{TS}_{\mathrm{s}}$} & 67 & 95 & 80 & 20 & 3 & 21 & $20-3-20 / 95$ \\
\hline & 77 & 95 & 85 & 20 & 5 & 20 & $20-10-20 / 95$ \\
\hline & 67 & 110 & 80 & 15 & 1 & 22 & $15-1-22 / 110$ \\
\hline & 68 & 110 & 85 & 20 & 5 & 20 & $20-5-20 / 110$ \\
\hline \multirow{4}{*}{$\mathrm{TS}_{\mathrm{E}}$} & 63 & 95 & 80 & 20 & 3 & 21 & $20-3-20 / 95$ \\
\hline & 62 & 95 & 85 & 20 & 10 & 22 & $20-10-20 / 95$ \\
\hline & 71 & 110 & 80 & 15 & 1 & 22 & $20-1-22 / 110$ \\
\hline & 71 & 110 & 85 & 20 & 5 & 24 & $20-5-24 / 110$ \\
\hline
\end{tabular}

Calculation of $F$-value for experimental tomato sauces

F-value is an equivalent exposure time to moist-heat conditions related to a specific temperature $\mathrm{T}$ and to a specific value of $\mathrm{z}$ [10]. F-value refers to the amount of heat treatment received in the critical thermal point (the cold point), where heating is the slowest. For solid canned foods it is the centre of the can/glass jar. By measuring the product temperature in the time interval $1 \mathrm{~min}$ through inserting the loggers into the glass jars during thermal treatment, the achieved F-value was determined. $F_{85}=5$ min with $\mathrm{z}=8.9$ were used as reference value in the study. The temperature was measured starting from the heating process till the end of cooling. F-value was calculated as follows [11]:

$$
F=\Delta t \Sigma 10^{\frac{T-T_{r e f}}{z}},
$$

where: $\Delta t$ - time interval between two next measurements, min;

$T$ - temperature of the treated product at time, ${ }^{\circ} \mathrm{C}$;

$z$ - temperature coefficient;

$T_{\text {ref }}$ - reference temperature, ${ }^{\circ} \mathrm{C}$.

Methods of analysis

The samples were tested according to the scheme given in Figure 1.

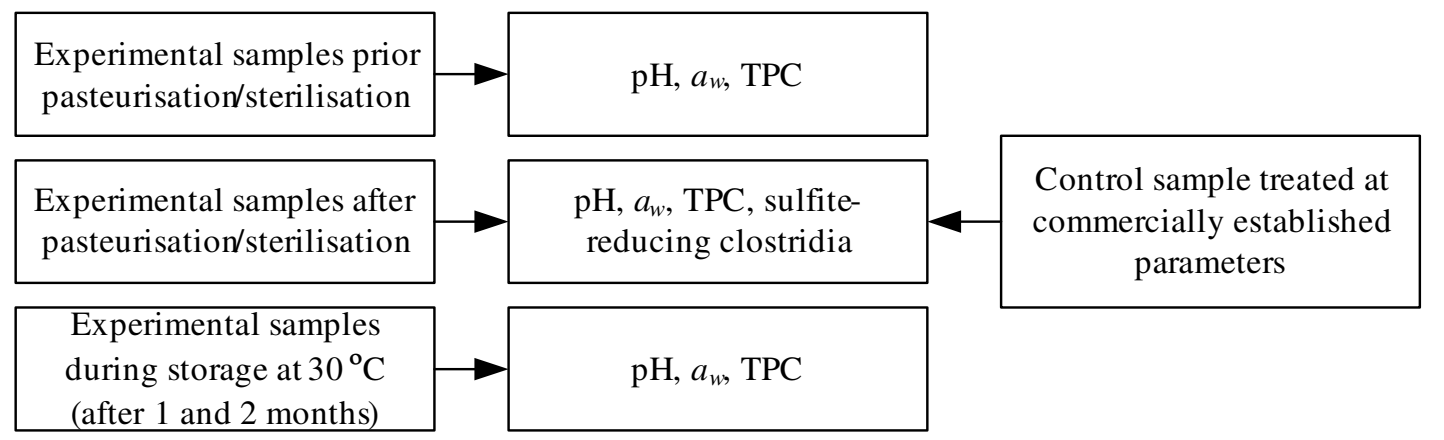

Fig. 1. Scheme of experimental and control samples analysis 
The following quality parameters were determined according to standard methods: $\mathrm{pH}$, water activity, total plate count and the colony forming units of sulfite-reducing clostridia.

pH was analysed according to ISO 1842:1991 "Fruit and vegetable products. Determination of pH" using the pH-meter $3510 \mathrm{pH}$-meter Jenway (Barlword Scientific Ltd, Essex, UK). Prior analysis the electrode was calibrated with buffer solution $(\mathrm{pH} 4.01,7.00)$. All analyses were made in 3 replications.

Water activity was measured with Lab Swift $a_{w}$ (Novasina, Switzerland) in 3 replications for each tested sample.

Total plate count was established according to ISO 4833-2:2013 "Microbiology of the food chain. Horizontal method for the enumeration of microorganisms. Part 2 . Colony count at $30^{\circ} \mathrm{C}$ by the surface plating technique".

The colony forming units of sulfite-reducing clostridia were detected according to ISO 15213:2003 standard "Microbiology of food and animal stuffs. Horizontal method for the enumeration of sulfite-reducing bacteria growing under anaerobic conditions".

Descriptive statistics were carried out to determine the differences of $\mathrm{pH}, a_{w}$ and total plate count in the analysed samples during accelerated shelf life storage.

\section{Results and discussion}

Kinetic models can be developed to predict important parameters for tomato sauces production optimization, monitoring, process verification and control. These are experimentally validated. The reference value $\left(F_{85}^{8.9}=5 \mathrm{~min}\right)$ does not mean that this is the optimal thermal treatment temperature. For any other relevant temperature, the F-value should be determined. The calculated F-values for thermally treated tomato products in glass jars are summarized in Table 5.

Table 5

Experimental tomato sauces $\mathbf{F}$ values

\begin{tabular}{|c|c|c|c|}
\hline Samples & Code & F-value & Time-temperature combinations \\
\hline \multirow{4}{*}{ Classical tomato sauce } & \multirow{4}{*}{$\mathrm{TS}_{\mathrm{c}}$} & 8.78 & $20-3-21 / 95$ \\
\hline & & 16.98 & $20-10-20 / 95$ \\
\hline & & 1.09 & $15-1-22 / 110$ \\
\hline & & 8.10 & $20-5-20 / 110$ \\
\hline \multirow{4}{*}{$\begin{array}{l}\text { Tomato sauce with } \\
\text { seasonings }\end{array}$} & \multirow{4}{*}{$\mathrm{TS}_{\mathrm{s}}$} & 3.80 & $20-3-20 / 95$ \\
\hline & & 23.54 & $20-10-20 / 95$ \\
\hline & & 18.44 & $20-5-20 / 110$ \\
\hline & & 3.36 & $15-1-22 / 110$ \\
\hline \multirow{4}{*}{$\begin{array}{l}\text { Tomato sauce without } \\
\text { food additives }\end{array}$} & \multirow{4}{*}{$\mathrm{TS}_{\mathrm{E}}$} & 2.77 & $20-3-20 / 95$ \\
\hline & & 8.95 & $20-10-20 / 95$ \\
\hline & & 2.90 & $20-1-22 / 110$ \\
\hline & & 27.14 & $20-5-24 / 110$ \\
\hline
\end{tabular}

F-value calculation showed that the chosen time-temperature combinations 20-10-20/95 and 20-5$20 / 110$ or 20-5-24/110 can fulfil the recommendations used for tomato products which are stored at ambient temperature. Also the time-temperature combination 20-3-20/95 for $\mathrm{TS}_{\mathrm{c}}$ samples corresponds to the reference value. The same amount of heat treatment can be achieved when using lower temperature/longer heat treatment time or hot product treatment prior pasteurisation/sterilisation. The F-values, which were obtained during the same time-temperature combination (20-3-20/95), showed that the temperature of product prior treatment in the jars plays an important role. If sugar or starch is added to the product, a time-temperature combination for higher $\mathrm{pH}$ should be used (see Table 1). Based on the results, the samples with the F-value above 5 were used for further study.

Analysis of sulfite-reducing clostridia in the experimental samples established that the concentration of the previously mentioned representatives was below the detection limit $<10 \mathrm{CFU} \cdot \mathrm{g}^{-1}$ [12]. Microbial inactivation level depends on the temperature and holding time combination, as well as the factors related to the food product, such as water activity or $\mathrm{pH}$. 
The $\mathrm{pH}$ of products is also a key factor, it works in synergy with the treatment process. A more effective microbial inactivation by pasteurisation/sterilisation is reached at a lower $\mathrm{pH}$ or $a_{w}$ (see Figure 2, 3 and 4).

a) 4,20

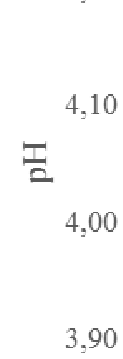

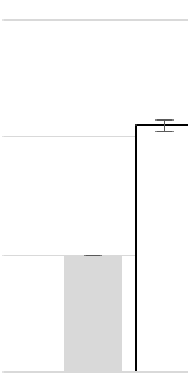

$20-10-20 / 95$

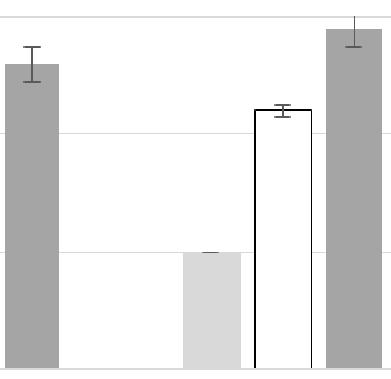

$20-5-24 / 110$ b)

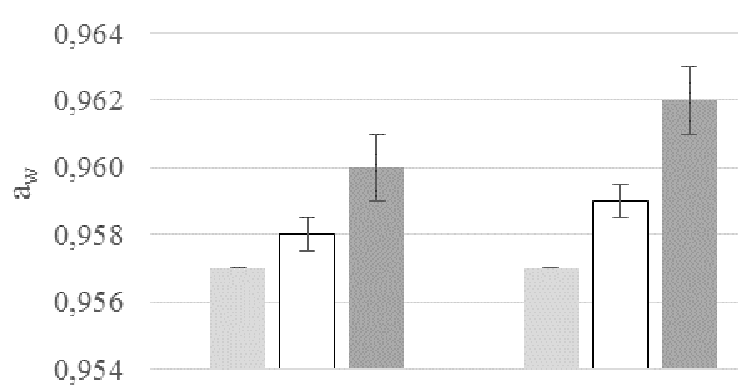

$20-10-20 / 95$

$\square$ after treatment $\square$ after 1 months $\square$ after 2 months

c)

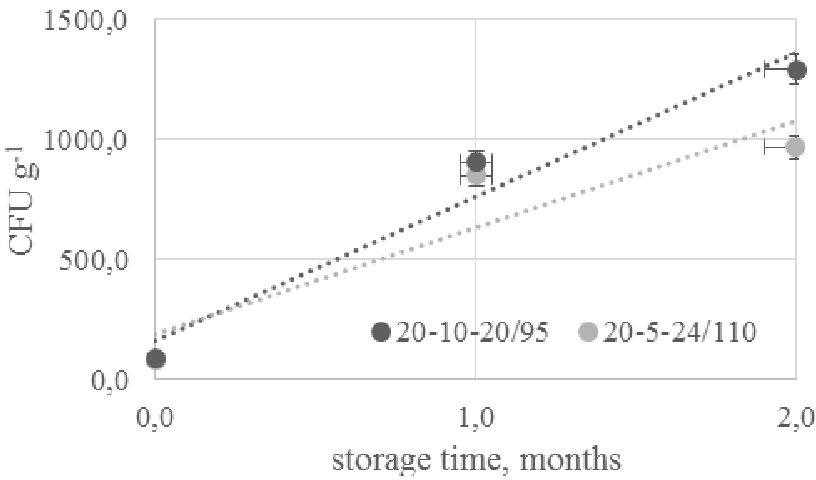

Fig. 2. Changes of $\mathbf{p H}(\mathbf{a}), \boldsymbol{a}_{w}$ (b) and total plate count (c) in experimental $\mathbf{T S}_{\mathrm{E}}$ samples during storage time

a)

$$
\begin{array}{r}
4,20 \\
{ }_{4,00} \\
4,10 \\
3,90
\end{array}
$$

b)

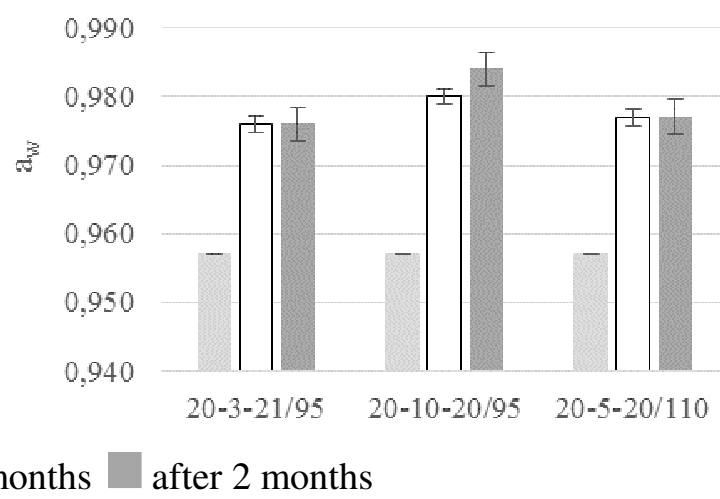

c)

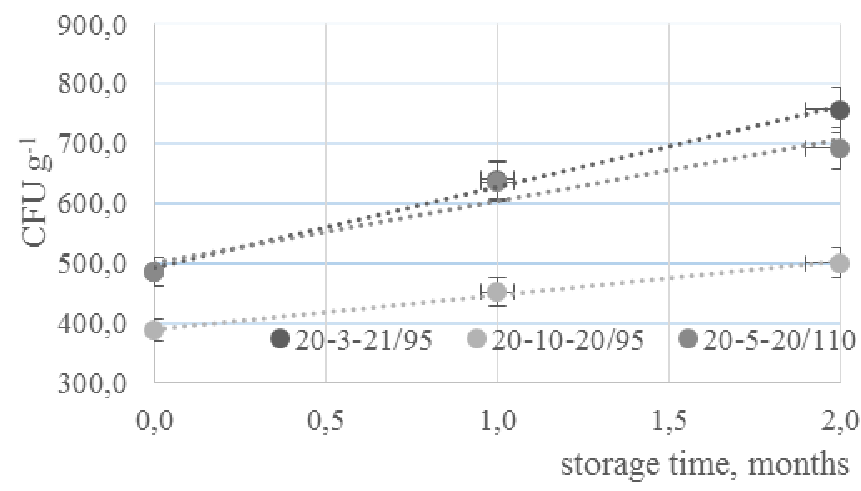

Fig. 3. Changes of $\mathbf{p H}(\mathbf{a}), \mathbf{a}_{\mathbf{w}}$ (b) and total plate count (c) in experimental $\mathbf{T S}_{\mathrm{c}}$ samples during storage time 
The data in Figure 2 showed that the $\mathrm{pH}$ and $\mathrm{a}_{\mathrm{w}}$ of the analysed experimental $\mathrm{TS}_{\mathrm{E}}$ samples were lower using the time-temperature combination 20-10-20/95. In contrast, the treatment of the samples at $110^{\circ} \mathrm{C}$ temperature resulted in a lower total plate count. Significant variations $(p<0.05)$ were found in the $\mathrm{pH}(p=0.001 ; p=0.003)$ and total plate count $(p=0.006 ; p=0.003)$ of the samples treated at the tested time-temperature conditions during accelerated storage time.

The data in Figure 3 showed that the $\mathrm{pH}$ and total plate count of the experimental $\mathrm{TS}_{\mathrm{c}}$ samples were lower at time-temperature combination 20-10-20/95. The lowest total plate count resulted from the longer exposing time at the selected temperature, which might cause a higher microorganism inactivation level with less variations for the survived microorganism growth during accelerated storage time. In contrast, treatment of the samples at $80^{\circ} \mathrm{C}$ temperature in the core of the product (20$3-21 / 95)$ resulted in the highest total plate count. Significant variations $(p<0.05)$ were found in the $\mathrm{pH}(p=0.0005 ; p=0.0008 ; p=0.0002)$ and $a_{w}(p=0.016 ; p=0.010 ; p=0.016)$ of the samples treated at the tested time-temperature conditions during accelerated storage time.

a)

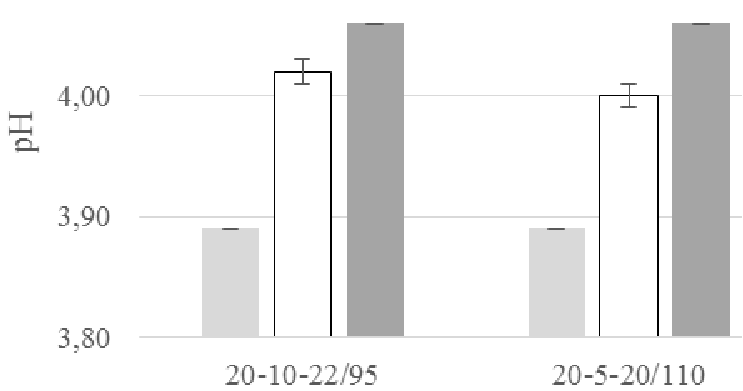

b) 0,970

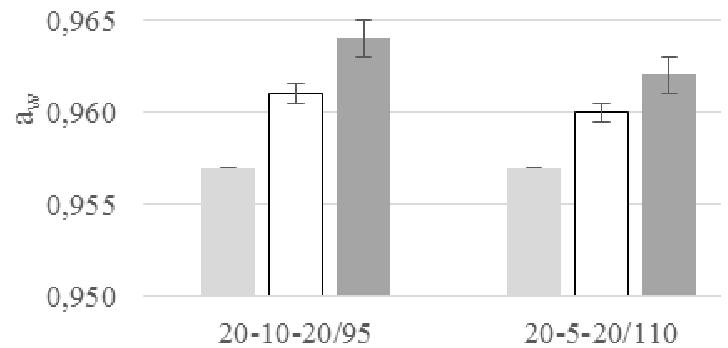

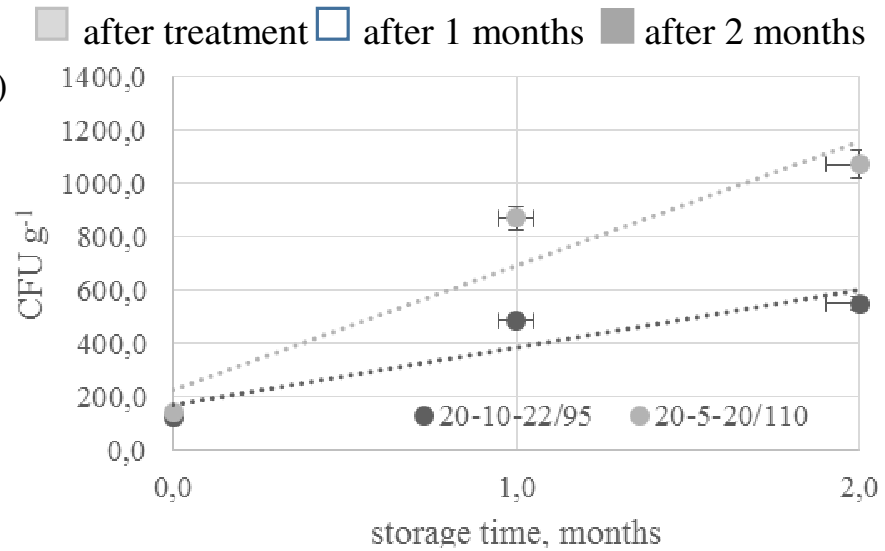

Fig. 4. Changes of $\mathbf{p H}, \boldsymbol{a}_{w}$ and total plate count in experimental $\mathrm{TS}_{\mathrm{s}}$ samples during storage

The data in Figure 4 showed that the total plate count of the experimental $\mathrm{TS}_{\mathrm{s}}$ samples was lower at the time-temperature combination 20-10-20/95, which is the result of longer exposure time at selected temperature. Significant variations $(p<0.05)$ were found in the $\mathrm{pH}(p=0.003)$ and total plate count of the samples $(p=0.010 ; p=0.007)$ treated at the tested time-temperature conditions during accelerated storage time.

The designed time-temperature conditions of the experimental samples showed that it is feasible to produce commercial tomato products at the tested time-temperature combinations (20-5-20/110 or 20-5-24/110 and 20-10-20/95), aiming to ensure safety and higher nutritional attributes.

Accelerated storage time study indicated that chemical reactions occur if the temperature is raised by $10^{\circ} \mathrm{C}(\mathrm{Q} 10)$. Experimental samples were stable for 2 months of the study at $30^{\circ} \mathrm{C}$ and their stability at $20^{\circ} \mathrm{C}$ will be at least 4 months. The product composition, as well as the ingredients used for tomato sauces production influence the product stability during shelf life and the chosen timetemperature condition 20-10-20/95 is appropriate for $\mathrm{TS}_{\mathrm{E}}$ and $\mathrm{TS}_{\mathrm{c}}$, and 20-5-20/110 for $\mathrm{TS}_{\mathrm{s}}$ samples. 


\section{Conclusions}

1. Experimentally chosen thermal treatment parameters showed that the reference F-value can be achieved by using $20-10-20 / 95$ and $20-5-20 / 110$ or 20-5-24/110 time-temperature combinations.

2. This research has shown the possibility to decrease the practised thermal treatment parameters on the commercial scale and maintain tomato sauces quality.

\section{Acknowledgements}

The present research leading to these results in accordance with the contract No. 1.2.1.1/16/A/004 between the Latvian Food Competence Centre Ltd. and the Central Finance and Contracting Agency (01.10.2016) has been conducted by Kronis Ltd with the support from the European Regional Development Fund (ERDF) within the framework of the project Latvian Food Industry Competence Centre.

\section{References}

[1] Augḷu un dārzeņu konservu ražošana. Konservēšanas alternatīvās metodes. Vadlīnijas (Canned fruit and vegetable production. Advanced canned methods. Guidelines). Riga, 2017. 73 lpp. (In Latvian).

[2] European Chilled Food Federation (ECFF). (2006). Recommendations for the production of prepacked chilled food, 2nd ed. [online] [12.03.2019.]. Available at: https://www.ecff.net/wpcontent/uploads/2018/10/ECFF_Recommendations_2nd_ed_18_12_06-2.pdf

[3] Taylor K., Crosby D. International pasteurization manual. Heinz Technical Manual, Heinz UK, Nov, 2006.

[4] Holdsworth D., Simpson R. Thermal processing of packaged foods. $2^{\text {nd }}$ ed. Springer, New York, 2007. $516 \mathrm{p}$.

[5] Tucker G. A novel validation method: Application of time-temperature integrators to food pasteurisation treatment. TransIChemE, Vol. 77, September, 1999, pp. 223-231.

[6] Tucher G., Featherstone S. Essentials of thermal processing. Wiley/Blackwell, Chichester. 2011. $288 \mathrm{p}$.

[7] Silva F.V.M., Gibbs P.A. Target selection in designing pasteurization processes for shelf-stable high-acid fruit products. Critical Reviews in Food Science and Nutrition, 44, 2004, pp. 353-360.

[8] Kong F., Singh R.P. Chemical deterioration and physical instability of foods and beverages. In: Food and beverage stability and shelf life. Kilcast D., Subramaniam P. (Eds). Woodhead Publishing Limited, Cambridge. 2011. pp. 29-62.

[9] Stoforos N.G. Thermal processing. In: Handbook of food processing and engineering. Food Preservation. Varzakas T., Tzia K. (Eds). CRC Press, Boca Raton, New York. 2016. pp. 27-56

[10] Taoukis P.S., Tsironi T.S., Giannakourou M.C. (2015) Reaction Kinetics. In: Handbook of food processing and engineering. Tzia K. and Varzakas T. (Eds). CRC Press, Boca Raton, Florida. 2015. pp. 529-570.

[11] Toledo R.T. Fundamentals of food process engineering. $3^{\text {rd }}$ ed. Springer, New York. 2008. 449 p.

[12] ISO 15213:2003 standard "Microbiology of food and animal stuffs. Horizontal method for the enumeration of sulfite-reducing bacteria growing under anaerobic conditions". 